DOI: 10.17707/AgricultForest.63.3.14

\author{
Dragoljub MITROVIĆ, Radisav DUBLJEVIĆ, \\ Milan JUGOVIĆ, Marija MARKO $\check{\text {, Nenad ĐORĐEVIĆ }}{ }^{1}$
}

\title{
ENERGY CONSUMPTION AND ENERGY EFFICIENCY IN LUCERNE ENSILING
}

\begin{abstract}
SUMMARY
Ensilling represents more successful process of fresh grass mass storage than hay storage. Losses of dry matter in alfalfa silage start from 5 to 15\% (Jugović, 2012), and in the technological process of storing hay, drying under the influence of the sun heat are going up to $25-30 \%$ of the total leaf mass. Preparation of alfalfa can be done in the form of: hay, silage and haylage.

In this paper, the results of lucerne ensiling and haylaging in several variants using different machines and tractor aggregates are shown: combi

1. Aggregate tractor IMT-539 + power presses, Agronic Model R-500

2. Aggregate tractor IMT-540 + self-loading wagon Sip Pioneer-17.

3. Aggregate tractor IMT-577 DV + roller presses Deutz - Fahr GP 2.50.

Aggregate: tractor IMT-539 + power presses, Agronic Model R-500 combi, represents a significant technological solution in forming cylindrical bales, weighing 60-70 kg, wrapped with polyethylene foil. The average operating speed of an aggregate was 3,4 km/h. Power bale with an average weight of 67,5 $\mathrm{kg}$ was formed on the 135,5 m length of the pass, for $2.4 \mathrm{~min}$. The average volume of the formed bale $(57 \mathrm{~cm} \times 63 \mathrm{~cm})$ was $0,16 \mathrm{~m}^{3}$. Consumption of the polyethylene films for forming bales was $51.0 \mathrm{~m} \times 0.25 \mathrm{~m}$, which represents an area of $12,75 \mathrm{~m}^{2}$ per bale. The average productivity of the tested aggregate was $0,40 \mathrm{ha} / \mathrm{h}$ or $3,24 \mathrm{ha} /$ day. Productivity of the formed bales ranged from $21-27$ bales/h or 41-60 bales/ha, which represents the daily productivity of 162 bales per day. The average fuel consumption was 6.0 liters per hour or 15 liters per hectare.

Aggregate: tractor IMT - 540 + self-loading wagon Sip Pioneer-17 in the working process performs loading and transport of semi-withered alfalfa plant mass to the trench silos. In the working process, the consumption of the fuel was 8.0 litters per hectare. In the process of lucerne ensiling compression (treading) of the delivered grass mass with the tractor T-40, whose consumption of diesel fuel is $11,5 \mathrm{l} / \mathrm{h}$, is necessary.
\end{abstract}

\footnotetext{
${ }^{1}$ Mitrović Dragoljub, Dubljević Radisav., Markoč Marija (corresponding author: marija.markoc@tcom.me)., University of Montenegro, Biotechnical faculty, Podgorica, MONTENEGRO; Jugović Milan, Faculty of Agriculture, East Sarajevo, BOSNIA AND HERZEGOVINA; Đorđević Nenad, University of Belgrade, Faculty of Agriculture, Belgrade, SERBIA.

Notes: The authors declare that they have no conflicts of interest. Authorship Form signed online.
} 
Aggregate: tractor IMT-577 DV + Power presses Deutz-Fahr GP 2.50 in ensiling achieved a diesel consumption of $15,16 \mathrm{l} / \mathrm{h}$. Power pressing is burden by wrapping power bundle with polyethylene foil. For this technological operation, a tractor IMT-577 DV + layer Sipma Z-557 was used, which has an average diesel fuel consumption of 3,64 liters per hectare.

Keywords: aggregate, tractor, power presses, productivity, energy, alfalfa (lucerne), silage, haylage.

\section{INTRODUCTION}

The preparation of silage and haylage represents the replacement for green cattle feed, because with contemporary approach of preparing bulk cattle feed, higher level of preservation in quality and nourishing values is achieved. The ensiling represents more successful process in conserving green mass than the process of making hay. The losses in dry matter during the ensiling process are from 5 to $15 \%$ (Jugović, 2012), and during the natural process of drying hay from 25 to $30 \%$. Volume mass (m3) is $700-1000 \mathrm{~kg} / \mathrm{m}^{3}$ or $150-300 \mathrm{~kg}$ of dry matter, comparing to unbaled hay $-70-80 \mathrm{~kg} / \mathrm{m}^{3}$ or $60-70 \mathrm{~kg}$ of dry matter (Hnatyszyn et al. 1988).

Preparation of silage and haylage is performing during the physiological phase of semi-withered plant and dry matter content of 35-40\% which make favorable conditions for starting the fermentation process (Jones, 1995). The important factor during the preparation of lucerne ensiling are anaerobic conditions, which stop fungi activities that lead to rotting. In order to get silage and haylage of higher quality, it is recommended to mow alfalfa before flowering phase (Ćupina, Dubljević, 2005). Mowing, crashing and drying the grass mass on time significantly influences the ensiling quality. The success of bale silage depends on quality, thickness and color of foil. According to Lingwall, 1995., the white color foil was more affordable than black foil. Preparation of silage and haylage with roller press, wrapping the bale with polyethylene foil has multiple advantages, because mowing and drying while the moisture is $30-50 \%$ last for several hours. In Western Europe, conservation of grass silage in the shape of bales with polyethylene foil is present in 56\% (Charney and Cherney, 1988).

Conservation of grass mass requests constant usage of machines during every operation, from mowing and preparing to wrapping and distribution in the object. If the average yield of semi-withered biomass with $45 \%$ of moisture is 9,54 t/ha, after finished process of ensiling, a feed with average metabolic energy (ME) of $10,7 \mathrm{MJ} / \mathrm{kg}$ will be obtained, which represents $102.078 \mathrm{MJ}$ ME per hectare (Jugović, 2012).

\section{MATERIALS AND METHODS}

Testing of the aggregate (A): Tractor-IMT-539 + roll press Agronic model - R 500 combi for forming cylindrical bales was done in 2012., on an area of lucerne (Silvija) production, nearby Nikšić. The production area of $\mathrm{p}=10740 \mathrm{~m}^{2}$ (length 358m and width $30 \mathrm{~m}$ ) was determined for testing. Mowing of lucerne 
was done by the rotary mower Sip - 165 that has width of $1,65 \mathrm{~m}$, in the aggregate of traction-power machine (tractor) IMT - 539.

Testing of the aggregate (B): tractor IMT $540+$ self-loading wagon Sip Pioneer-17; (C): tractor IMT-577 DV + Power presses Deutz-Fahr GP 2.50 layer Sipma Z-557 was done in 2012., on an area in Mokro, region Pala, the Republic of Srpska.

The parameters which were tracked during the aggregate testing in preparation of silage (baling of fresh mowed lucerne) are: aggregate flow length $(\mathrm{m})$, length of the crossed path in order to form bale (m), time needed for forming bale (min), aggregate working speed $(\mathrm{km} / \mathrm{h})$, dimensions of formed bale $(\mathrm{axb})$, mass of the formed bale $(\mathrm{kg})$, volume mass of the formed bale $(\mathrm{kg} / \mathrm{m} 3)$, consumption of polyethylene foil (m2), number of formed bales on tested area (piece). The consumption of fuel for an aggregate of power machine is determined by the engine type, engine power and consumption of fuel per hour $(\mathrm{l} / \mathrm{h})$.

The aggregate productivity in silage preparation is determined based on chronometric measurements and calculations: aggregate working speed, productivity of tested aggregate (ha/h), (ha/day), (bale/h), (bale/ha), (bale/day), based on the equation:

$$
\text { Wth }=0,1 \cdot B \cdot v(h a / h)
$$

$$
\mathrm{Wd}=\mathbf{0 , 1} \cdot \mathbf{B} \cdot \mathbf{v} \cdot \mathbf{n} \cdot \mathbf{T} \cdot \mathbf{t}(\text { ha/day) }
$$

B - aggregate working width (m)

$\mathrm{v}$ - aggregate working speed $(\mathrm{km} / \mathrm{h})$

$\mathrm{n}$ - coefficient of aggregate flow use

$\mathrm{T}$ - daily time (h)

t- coefficient of time use

\section{RESULTS AND DISCUSSION}

\section{Technical characteristics of the tested aggregates}

Technical characteristics of the tested aggregates in the silage preparation are presented in table 1 .

Table 1. Technical characteristics of the tested aggregate machines: A, B, C

\begin{tabular}{|c|c|c|c|c|}
\hline $\begin{array}{c}\text { Technical characteristics of } \\
\text { the tested aggregates }\end{array}$ & $\mathrm{L} / \mathrm{W} / \mathrm{H}(\mathrm{m})$ & $\begin{array}{c}\text { Required } \\
\text { power (kW) }\end{array}$ & Mass (kg) & $\begin{array}{c}\text { Pick - up } \\
(\mathrm{m})\end{array}$ \\
\hline $\begin{array}{c}\text { A - Agronic model R-500, } \\
\text { combi }\end{array}$ & $3,50 / 1,85 / 0,79$ & 30 & 790 & 1,50 \\
\hline $\begin{array}{c}\text { B - Self - loading wagon } \\
\text { SIP Pioneer 17 }\end{array}$ & $5,85 / 2,05 / 2,85$ & 30 & 1160 & 1,50 \\
\hline $\begin{array}{c}\text { C - Press for rounded } \\
\text { shaped bales Deutz - Fahr } \\
\text { GP 2-50 }\end{array}$ & $4,43 / 2,35 / 2,21$ & 60 & 1800 & 1,67 \\
\hline Bale layer Sipma Z.557 & - & 26 & 785 & $1,1-1,6$ \\
\hline
\end{tabular}




\section{Technological characteristics of the tested aggregates}

Technological process of Power press Agronic model R-500, combi

Power press Agronic model R-500, combi, is an attached machine, which is used for preparing hay, silage and haylage, lucerne and shamrock grazing mixtures, in round-shaped bales. Drive of the machine and the movable parts is accomplished from tractor's power take-off, via universal joint and hydraulic motor. Forming and wrapping the finished bale is automatic, and working progress is controlled on the monitor. During the technological process of work, power press's pick - up machines, with its elastic tines lift mowed grass mass from the slope and transport it through the pressing chamber. In the pressing chamber, grass mass is being twisted and bale is growing to the planned size. Joining belts lift and automatically pinch the grass mass, which makes the bale thick and solid. When the formed bale reaches planned size and mass, it is being tied up and wrapped with the polyethylene foil, and after that postponed on the agricultural area.

\section{Technological working process of Self-loading wagon SIP Pioneer 17}

Technological working process of Self-loading wagon consists of lifting the grass mass from the slope with a pick-up machine and transporting it to the transporting channel. There is a machine with whom the grass mass is being pushed in the wagon trunk. During the wagon dicharging, back side opens and grass mass is being pushed from the trunk via floor conveyor. The wagon has a system for chopping the grass mass size $40-100 \mathrm{~mm}$, for preparing silage and it needs a tracto with a power of $30-40 \mathrm{~kW}$.

Technological working process of roller press for round-shaped bales Deutz - Fahr GP 2.50

Technological working process of roller press consists of lifting the grass mass with pick-up machine, transporting to the retractable conveyor or directly inserting in the chamber for bale forming. In that chamber, there are specific working parts for rolling the hay. When the bale grows to the planned compactness and diametar, devices for tying up will be on, and the balle is going to be wrapped with the twine. Then, the chamber opens and bale is being postponed on the agricultural area. Roller bales can be wrapped up with the twine, they can be also wrapped up with the net, which is more traditional way, or tied up with the wire. After this step, bale is formed and it can be wrapped in plastic foil. The device for wrapping the bale with the foil lifts the formed bale to the turning mechanism (turning table or rollers), which wraps it. Wrapping must be equal and tight, and the bale has to be postponed without any damage.

\section{Parameters for working usage of the aggregate}

Parameters for working usage of the aggregate - A) tractor IMT-539 + power press Agronic-R 500 for silage preparing are shown in the Table 2.

The average working speed was $3,4 \mathrm{~km} / \mathrm{h}$. The bale with an average weight of $67,5 \mathrm{~kg}$ was formed on the $135,5 \mathrm{~m}$ flow length, which represents the average time of 2,4 min. The average volume mass of the formed bale $(57 \mathrm{~cm} \mathrm{x}$ 
$63 \mathrm{~cm}$ ) was $0,16 \mathrm{~m}^{2}$. Consumption of the polyethylene foil was 51,0 $\mathrm{m} \times 0,25 \mathrm{~m}$, which represents the surface of $12,75 \mathrm{~m}^{2} /$ bales.

Table 2: Parameters for working usage of the aggregate A): tractor IMT-539 + power press Agronic R-500

\begin{tabular}{|c|c|c|c|c|c|c|c|c|c|c|}
\hline $\begin{array}{c}\text { Aggreg. } \\
\text { flow }\end{array}$ & $\begin{array}{c}\text { Flow } \\
\text { length } \\
(\mathrm{m})\end{array}$ & $\begin{array}{c}\text { Flow } \\
\text { time } \\
(\mathrm{min})\end{array}$ & $\begin{array}{c}\text { Turn } \\
\text { time } \\
(\mathrm{min})\end{array}$ & $\begin{array}{c}\text { Bale } \\
\text { length } \\
\text { form. }\end{array}$ & $\begin{array}{c}\text { Bale } \\
\text { time } \\
\text { form. }\end{array}$ & $\begin{array}{c}\text { Vol. } \\
\text { form. } \\
\text { mass }\end{array}$ & $\begin{array}{c}\text { Bale } \\
\text { mass } \\
(\mathrm{kg})\end{array}$ & $\begin{array}{c}\text { Bale } \\
\text { vol. } \\
\text { mass } \\
\left(\mathrm{kg} / \mathrm{m}^{3}\right)\end{array}$ & $\begin{array}{c}\text { Foil } \\
\text { cons. } \\
\left(\mathrm{m}^{2}\right)\end{array}$ & $\begin{array}{c}\text { Bale } \\
\text { Flow }\end{array}$ \\
\hline Average & 358 & 6,42 & 0,32 & 135,50 & 2,40 & 0,16 & 67,50 & 422 & 12,75 & 2,70 \\
\hline
\end{tabular}

The results of tested aggregate productivity during the silage preparation are shown in Table 3.

Table 3: Aggregate productivity A): tractor IMT-539 + power press Agronic-R 500

\begin{tabular}{|c|c|c|c|c|c|c|c|}
\hline $\begin{array}{c}\text { Aggreg. } \\
\text { flow }\end{array}$ & $\begin{array}{c}\text { Work } \\
\text { speed } \\
(\mathrm{km} / \mathrm{h})\end{array}$ & $\begin{array}{c}\text { Prod. } \\
(\mathrm{ha} / \mathrm{h})\end{array}$ & $\begin{array}{c}\text { Prod. } \\
\text { (ha/day) }\end{array}$ & $\begin{array}{c}\text { Prod. } \\
(\mathrm{kg} / \text { day) }\end{array}$ & $\begin{array}{c}\text { Prod. } \\
\text { (bale/h) }\end{array}$ & $\begin{array}{c}\text { Prod. } \\
\text { (bale/ha) }\end{array}$ & $\begin{array}{c}\text { Prod. } \\
\text { (bale/day) }\end{array}$ \\
\hline Average & 3,4 & 0,40 & 3,24 & 10935 & 25 & 50 & 162 \\
\hline
\end{tabular}

Table 4: Energy consumption in working operations

\begin{tabular}{|c|c|c|c|c|c|c|}
\hline Aggregate & $\begin{array}{c}\text { Qh } \\
(\mathrm{l} / \mathrm{h})\end{array}$ & $\begin{array}{c}\text { Prod. } \\
\text { (ha/h) }\end{array}$ & $\begin{array}{c}\text { Prod. } \\
\text { (ha/day) }\end{array}$ & (l/ha) & $\begin{array}{c}\text { Energy } \\
\text { (MJ/ha) }\end{array}$ & $\begin{array}{c}\text { Energy } \\
\text { Eha } \\
\text { (kwh/ha) }\end{array}$ \\
\hline $\begin{array}{c}\text { 1.Mower RK 165 + } \\
\text { IMT539 }\end{array}$ & 5,5 & 1,2 & - & 6,6 & 270,6 & 10,50 \\
\hline $\begin{array}{c}\text { A)- Tractor IMT539 } \\
+\begin{array}{c}\text { roll presonic model } \\
\text { R 500 combi }\end{array}\end{array}$ & 6,5 & 0,4 & 3,24 & 2,6 & 106,6 & 12,50 \\
\hline $\begin{array}{c}\text { Cistern Kaiser 2800 } \\
\text { + IMT 540 }\end{array}$ & 7,9 & 1,2 & 9,6 & 9,5 & 454,10 & 9,93 \\
\hline RK 135+ IMT540 & 6,4 & 1,03 & 8,2 & 6,58 & 314,52 & 11,57 \\
\hline $\begin{array}{c}\text { Favorit 220+ } \\
\text { IMT540 }\end{array}$ & 2,1 & 1,3 & 10,4 & 2,72 & 130,02 & 4,72 \\
\hline $\begin{array}{c}\text { B.SiP Pioneer 17 + } \\
\text { IMT540 }\end{array}$ & 26,7 & 0,3 & 2,4 & 8,0 & 382,40 & 20,43 \\
\hline T.40 AS for treading & - & - & - & 11,5 & 549,70 & - \\
\hline $\begin{array}{c}\text { C.Deutz-Fahr } \\
\text { GP2,50 + IMT } \\
\text { 577DV }\end{array}$ & 33,7 & 0,45 & 3,6 & 15,16 & 724,65 & 57,24 \\
\hline $\begin{array}{c}\text { SipmaZ-557 + IMT } \\
\text { 577DV }\end{array}$ & - & - & - & 3,64 & 173,99 & - \\
\hline
\end{tabular}

Productivity of the tested aggregate was $0,40 \mathrm{ha} / \mathrm{h}$ average or 4,24 ha/day. The average yield of the lucerne was $3330 \mathrm{~kg} / \mathrm{h}$. Productivity in forming bales 
was going from 21 to $27 \mathrm{bales} / \mathrm{h}$ or from 41 to $60 \mathrm{bales} / \mathrm{ha}$, which represents the daily productivity of 162 bales per day.

In order to determine energetic inputs for agrotechnical operations in silage production (fertilization, mowing, rolling over, collecting the mowed mass), methods for measuring the amount of fuel consumed in working process were applied.

A statistically significant difference in the energy efficiency of direct inputs of grass silage production, depending on the way and selection of the mechanization for storing (round shaped bales wrapped in the foil, silo mass tight in silo and covered with foil) was done by testing, by standard statistical methods of the mean values of the basic energy parameters, tested with t-test.

$$
\begin{gathered}
\mathbf{H}_{\mathbf{0}}: \bar{d}=\mathbf{0} s_{d d}=\sqrt{\frac{\sum(d \bar{l}-\bar{d})^{2}}{n-1}} \\
\mathbf{t}_{\exp }=\frac{d}{s_{\bar{d}}} \mathbf{t}_{\exp }<\mathbf{t}_{\text {tab }} \rightarrow \operatorname{accept} \mathbf{H}_{0} \\
s_{d}=\frac{s_{d}}{\sqrt{n}} \mathbf{t}_{\exp }>\mathbf{t}_{\text {tab }} \rightarrow \text { reject } \mathbf{H}_{\mathbf{0}}
\end{gathered}
$$

\section{Energetic parameters}

During the energy analysis, the metodology given by Ortiz-Canavante and Hernanz (1999) was used, and that method predicts the determination of energy input and output, based on the mesured values of fuel consumption and achieved yield. Based on the obtained values, next parameteres are determined: Specific energetic input (EL), Energetic relation (ER) and Energetic productivity (EP).

Specific energetic input $(\mathrm{EL})=\frac{\text { Energetic input in the production cycle }\left(\frac{\mathrm{MJ}}{\mathrm{ha}}\right)}{\text { Output }\left(\frac{\mathrm{kg}}{\mathrm{ha}}\right)}(\mathrm{MJ} / \mathrm{kg})$

Energetic relation $(\mathrm{ER})=\frac{\text { Energeticproduction value }\left(\frac{\mathrm{MJ}}{\mathrm{ha}}\right)}{\text { Energetic input in the production cycle }\left(\frac{\mathrm{MI}}{\mathrm{ha}}\right)}$

Energetic productivity $(\mathrm{EP})=\frac{\text { output }\left(\frac{\mathrm{kg}}{\mathrm{ha}}\right)}{\text { Energetic input in the production cycle }\left(\frac{\mathrm{MJ}}{\mathrm{ha}}\right)}(\mathrm{kg} / \mathrm{MJ})$

In the work of the aggregate A: tractor IMT-539 + power press Agronic R500 , total fuel consumption was $6,5 \mathrm{l} / \mathrm{h}$ or $2,6 \mathrm{l} / \mathrm{ha}$.

In the work of the aggregate B: self-loading wagon Sip Pioneer $17+$ tractor IMT 540, total fuel consumption was 26,7 or $8,0 \mathrm{l} / \mathrm{ha}$.

In the work of the aggregate C: roller pess Deutz-Fahr GP + tractor IMT 577. DV), total fuel consumption was $33,7 \mathrm{l} / \mathrm{h}$ or $15,16 \mathrm{l} / \mathrm{ha}$. It is important to mention that the aggregate $\mathrm{B}$ is being burdened by the tractor for silage hitting in trench silo T-40 AS (aggregate Ba) with consumption of 11,5 l/ha of fuel. Also, the aggregate $\mathrm{C}$ is being burdened by the tractor IMT 577+layer SIPMA for wrapping the bales, as well as transportation to the object with fuel consumption of 3,64 l/ha. Energy paramters for fertilization, mowing, grabbing and methods of grass harvesting are shown via fuel consumption per area unit Qha (l/ha), and 
for fuel thermal power, the unit of $41,0 \mathrm{MJ} / \mathrm{l}$ or $47,8 \mathrm{MJ} / \mathrm{kg}$ were taken (OrtizCanavate and Hermanz, 1999). Direct energetic inputs in preparation of grass silage were tracked and processed based on the fuel energy for the drive of technical systems.

Table 5. Total direct inputs in silage preparation (MJ/ha)

\begin{tabular}{|c|c|c|c|c|c|}
\hline Operation & Fertilization & Mowing & Grabbing & Picking & Total \\
\hline $\begin{array}{l}\text { Direct inputs } \\
\text { (MJ/ha) }\end{array}$ & 454,10 & 314,52 & 130,02 & \begin{tabular}{|} 
Pioneer $17+$ silo \\
wading \\
932,1 \\
Deutz-fahr GP 2,50 \\
+ wrapping \\
898,64
\end{tabular} & $\begin{array}{c}\text { Aggregate B } \\
1830,74 \\
\text { Aggregate C } \\
1797,28\end{array}$ \\
\hline
\end{tabular}

Energy output of cattle feed production can be determined via achieved yield and heat value of the given nutrition. Energetic value of grass silage is 0,441 oats units per kilogram or 5,04 MJ/kg of gross energy.

Table 6. Energy balance of direct energetic inputs of haylage production

\begin{tabular}{|c|c|c|}
\hline & $\begin{array}{c}\text { Self-loading wagon } \\
\text { Aggregate - B }\end{array}$ & $\begin{array}{c}\text { Roller press } \\
\text { Aggregate - C }\end{array}$ \\
\hline Direct energetic inputs (MJ/ha) & 1830,74 & 1797,28 \\
\hline Silage yield (kg/ha) & 9540 & 9540 \\
Energetic output (MJ/ha) & 40988,61 & 43663,63 \\
\hline Specific energetic input (EL) & 0,192 & 0,188 \\
Energetic relation (ER) & 22,389 & 24,294 \\
Energetic productivity (EP) & 5,211 & 5,308 \\
\hline
\end{tabular}

Table 7: Share of direct inputs in different variations of silage storing

\begin{tabular}{|c|c|c|c|c|c|}
\hline \multicolumn{2}{|c|}{ Operation } & $\begin{array}{l}\text { Energy } \\
\text { (MJ/ha) }\end{array}$ & $\begin{array}{c}\text { Percentage } \\
\text { share \% }\end{array}$ & $\begin{array}{l}\text { Energy } \\
\text { (MJ/ha) }\end{array}$ & $\begin{array}{c}\text { Percentage } \\
\text { share } \%\end{array}$ \\
\hline \multicolumn{2}{|c|}{ Fertilization } & 454,10 & 24,80 & 454,10 & 25,27 \\
\hline \multicolumn{2}{|c|}{ Mowing } & 314,52 & 17,18 & 314,52 & 17,50 \\
\hline \multicolumn{2}{|c|}{ Grabbing } & 130,02 & 7,10 & 130,02 & 7,23 \\
\hline \multirow{2}{*}{ Aggregation } & Aggregate $\mathrm{B}$ & 382,40 & 20,89 & 724,65 & - \\
\hline & Aggregate $\mathrm{C}$ & - & - & - & 40,32 \\
\hline \multicolumn{2}{|c|}{ Hitting } & 549,70 & 30,03 & - & - \\
\hline \multicolumn{2}{|c|}{ Wrapping } & - & - & 173,99 & 9,68 \\
\hline \multicolumn{2}{|c|}{ Total } & 1830,74 & 100,00 & 1797,28 & 100,00 \\
\hline
\end{tabular}

The average yield of lown green mass at tested areas was $21,2 \mathrm{t} / \mathrm{ha}$ and the yield of semi-dried mass with moisture of $45 \%$ was 9,54 t/ha. After chemical analysis of given silage examples and yields, it is established:

Energetic value of production $(\mathrm{MJ} / \mathrm{ha})=4296,5 \mathrm{~kJ} / \mathrm{kg} \times 9,54 \mathrm{~kg} / \mathrm{ha}=$ $40988,610 \mathrm{~kJ} / \mathrm{ha}=40988,61 \mathrm{MJ} / \mathrm{ha}$ for energetic value of silage from silo. 
Energetic value of production $(\mathrm{MJ} / \mathrm{ha})=4576,9 \mathrm{~kJ} / \mathrm{kg}$ x $9540 \mathrm{~kg} / \mathrm{ha}=43663,626$ $\mathrm{kJ} / \mathrm{ha}=43663,63 \mathrm{MJ} / \mathrm{ha}$ for energetic value of silage from rounded shaped bales.Among total direct inputs, the highest share have the inputs of fuel consumption in a process of hitting a silo mass - 30,33\% with self-loading wagon, and $40,32 \%$ in a working process of press for baling. Lower inpusts are in a proess of grabbing the mowed grass and in a process of bale unwinding.

The impact of chosen ensiling type on basic energetic parameters of grass silage production

In order to compare and statisticly analyze basic energetic parameters of grass silage production with two different aggregates, we have chosen two cases with average sillage mass yield of 9,54 t/ha and 6,75 t/ha.

Table 8: Parameters for statistic analysis

\begin{tabular}{|c|c|c|c|c|}
\hline $\begin{array}{c}\text { Energetic } \\
\text { parameters }\end{array}$ & $\begin{array}{c}\text { Aggregate B } \\
\text { Yield 9,54 t/ha }\end{array}$ & $\begin{array}{c}\text { Aggregate C } \\
\text { Yield 9,54 t/ha }\end{array}$ & $\begin{array}{c}\text { Aggregate B } \\
\text { Yield 6,75 t/ha }\end{array}$ & $\begin{array}{c}\text { Aggregate C } \\
\text { Yield 6,75 t/ha }\end{array}$ \\
\hline EL (MJ/kg) & 0,192 & 0,188 & 0,271 & 0,266 \\
\hline ER & 22,389 & 24,294 & 15,841 & 17,189 \\
\hline EP (kg/MJ) & 5,211 & 5,308 & 3,687 & 3,756 \\
\hline
\end{tabular}

Table 9a: Display of test results with an average yield of 9,54 t/ha

\begin{tabular}{|c|c|c|c|c|}
\hline $\mathrm{X}_{1}$ & $\mathrm{X}_{2}$ & $d_{i}$ & $d i-\bar{d}$ & $(d i-\bar{d})^{I}$ \\
\hline 0,192 & 0,188 & 0,004 & 0,67 & 0,449 \\
\hline 22,389 & 24,294 & $-1,905$ & $-1,239$ & 1,535 \\
\hline 5,211 & 5,308 & $-0,097$ & 0,569 & 0,324 \\
\hline & \multirow{3}{*}{$\sum_{d}$} & $-1,998$ & & 2,308 \\
\hline & & $\bar{d}=-0,666$ & & \\
\hline & & $t_{\text {exp }}=-1,074$ & & \\
\hline
\end{tabular}

Table 9b: Display of test results with an average yield of 6,75 t/ha

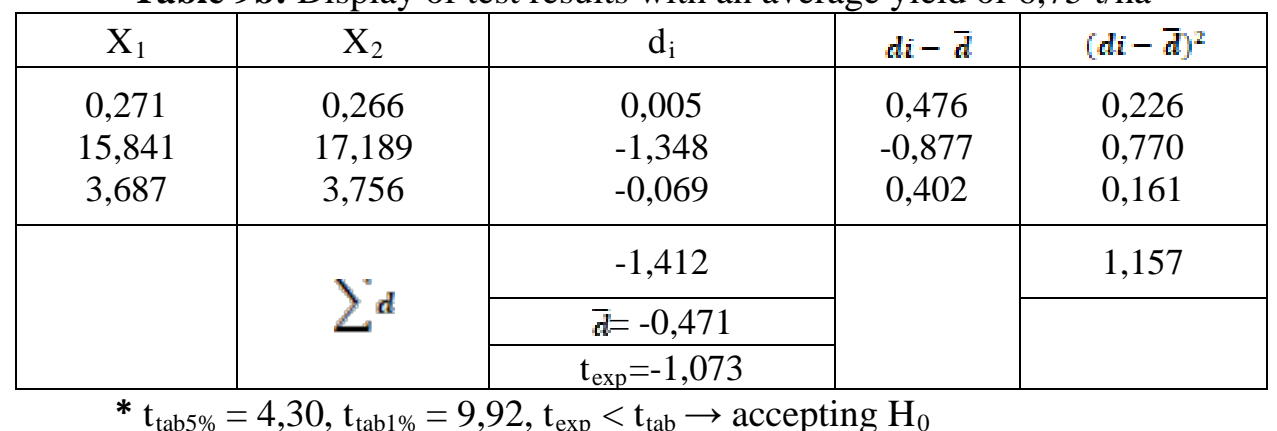

Based on the test results, it is established that experimental values (t-test) are lower than values from the table (f) for both significance $(0,05$ and 0,01$)$, 
which means that there are no significant difference in the way of grass silage ensiling with aggregate $-\mathrm{B}$ and aggregate $-\mathrm{C}$.

\section{CONCLUSION}

Tested aggregate A-(power press, Agronic model R-500 combi + tractor IMT-539) in lucerne ensiling in cylindric shaped bales wrapped with polyethylene film, achieved average working speed of $3,4 \mathrm{~km} / \mathrm{h}$, with the average time for bale forming of 2,4 min per bale. There was a huge impact of lower alfalfa yield (in 4th swath it was $3330 \mathrm{~kg} / \mathrm{ha}$ ) on time needed for bale forming. In a working process of the aggregate-A: tractor IMT-539+power presses Agronic$\mathrm{R} 500$, the total fuel consumption was $6,5 \mathrm{l} / \mathrm{h}$ or $2,6 \mathrm{l} / \mathrm{ha}$, which represents the energy of 106,6 MJ/ha.

Tested power press Agronic model R-500 combi, represents technical and technological solution in hay, silage and haylage preparation on smaller production areas with fodder crops, lucern and shamrock-grass mixtures. The tested power press is suitable for baling fodder crops on mountain areas, where there is no storages for bulk cattle feed (hay) and on lean terrains of natural and artificial lawns.

Total fuel consumption in aggregate-B working process was 19,5l and in aggregate-C working process, it was 18,80 l which leads to conclusion that, in our case, the highest consumption in grass silage preparing is in a process of hitting a silo mass, $30 \%$ with self-loading wagon (aggregate 1), or $40 \%$ in a process of pressing roller bales (aggregate $\mathrm{C}$ ).

In the case of total direct inputs, the fuel consumption inputs in the loading process had a maximum load of $30 \%$ in the variant with a self-loading trailer (aggregate 1 ) and $40 \%$ for the rolling baling process (aggregate $\mathrm{C}$ ).

Energy and fuel consumption in the agrotechnical operatios were 20,43 $\mathrm{kWh} / \mathrm{ha}$ with aggregate $\mathrm{B}$ and $57,24 \mathrm{kWh} / \mathrm{ha}$, with high coefficient of fuel utilization of $19,23 \%$ and $28,44 \%$.

Total energy value of produced silage from silo is $40988,61 \mathrm{MJ} / \mathrm{ha}$, but the energetic value of silage from rounded shaped bales is 43663,63 MJ/ha.

By the energy analysis of direct inputs in the production of grass silage, we have come to the conclusion that there are no statistical deviations in the mentioned parameters for silage variants ( $\mathrm{B}$ and $\mathrm{C}$ ), which was confirmed by the results of testing the hypothesis on the equality of mean values of two basic sets meaning that there is no significant difference in ensiling mode on the total balance of direct inputs of production.

Based on the given data, we see the dependence on the production and preparation of grass silage from direct inputs (fuel consumption) for both preparation methods. However, grass silage, as the basic bulk nutrient in cattle breeding, has a relatively high energy value, and for that reason, it is understandable that a fairly high degree of energy utilization, ie, the ratio of outputs and total direct energy inputs in the production cycle. 


\section{REFERENCES}

Barać S., Đević M., Mratinić B.: Mehanizacija ubiranja. Univerzitet u Prištini, Poljoprivredni fakultet, Zubin Potok, 2007.

Cherny J.H.and Cherney D.J.R.(1998): Grass for Diary Cattl.CAB.

Ćupina B.,Dubljević R.(2005): Konzerviranje i čuvanje krme sa prirodnih travnjaka. Unapređenje proizvodnje krme na prirodnim travnjacima. Sarajevo.

Forristal D.(1995): Big Bale Silage ,Cattle Production Semior for Teagase Beet Adviosors and College Teachers, Tegasc, Ireland.

Haingh P.M.(1995): Chemical composition of energy value of big bale silages mode in England.Journal of Agricultural Research.

Jones. R.(1995): Big bale silage, Can We sfford them, Internal Worc Document.Institute of Grassland and Euvironmetal Recearch (IGER) Aberystwyth.

Lngwall P.(1995): The Balewrapping handbook.Trioplat AB.Smolandsstenor Savoie.P.(1988): Optimization of Plastic Covers for Stack Silos. Jurnal of Agricultural Engeneering Research.

Đukić D., Stevović V., Janjić V.: Proizvodnja stočne hrane na oranicama i travnjacima, Univerzitet u Novom Sadu, Poljoprivredni fakultet, Novi Sad, Univerzitet u Kragujevcu, Agronomski Fakultet, Čačak, 2009.

Fluck, R. C. And C. D. Baird : Agricultural Energetics, Westport, Connecticut, p. 41-71, 1982.

Forristal P.D. and O' Kiely P.O. (2005): Silage production and utilisation (Update on tehnologies for producing and feeding silage) Proceedings of the XIVth International Silage Conference, a satellite workshop of the XXth International Graasland Congress, July 2005, Belfast, Northern Ireland.

Hnatyszyn M., Guais A. (1988): Les fourrages et l'leleveur. Agriculture d`Aujourd hui, Paris

Mikkola H., Ahokas J.: Energy Management of Future Farms, University of Helsinki, Department of Agrotechnology, Agronomy Research 2010. Ortiz.Canavate J., Hernanz J. L.: Energy Analysis and Saving, Energy for Biological Systems, CIGR Handbook, 1999.

Radivojević D., Tošić M.: Mehanizacija pripreme stočne hrane, Univerzitet u Beogradu, Poljoprivredni Fakultet, Beograd, 2000.

Zeremski D.,Tošić M.: Silaža i siliranje u stočarstvu, Niro-Zadrugar, Sarajevo, 1981. http://agronomy.emu.ee

http://www.imt.co.rs

http://www.sano.ba/node/404

http://www.sip.si

http://www.izvorienergije.com 